\title{
Illustrations Part I
}

Cover: Voortrekker Monument, Hall of Heroes, east section of south frieze (courtesy of VTM; photo Russell Scott)

Frontispiece: Aerial view of Voortrekker Monument in 1949: building site with ramps for transporting the completed marble panels into the Hall of Heroes (photo courtesy of Unisa Archives, Van Schaik album)

Figure 1: Gerard Moerdyk. Voortrekker Monument, north façade (photo Russell Scott)

Figure 2: Voortrekker Monument, cenotaph lit by sunray, 16 December 2013 (https://gdb.voanews.com/E7B533D71CFE-49C7-A838-0CB16AB50460_w1597_n_st.jpg)

Figure 3: Gerard Moerdyk. Voortrekker Monument, Hall of Heroes (courtesy of VTM; photo Russell Scott)

Figure 4: Plan with layout of scenes of the frieze in Hall of Heroes (drawing Tobias Bitterer)

Figure 5a: Conflicting light conditions in Hall of Heroes. 21.7.2012 (courtesy of VTM; photo the authors)

Figure 5b: Russell Scott. Photographs taken of the east frieze during the day showing changing light. 2015 (courtesy of VTM)

Figure 5c: Russell Scott. Photographs taken of the north frieze at night using suspended white light reflecting panels and flashes aiming at them. 19.3.2015 (courtesy of VTM)

Figure 5d: Russell Scott. Photographs of the east frieze taken in eleven sections, each in parallax. 2015 (courtesy of VTM)

Figure 6: Routes of the main treks. 1835-38 (the authors; drawing Janet Alexander)

Figure 7: Aaron Arrowsmith. South Africa. London, 1815. h. 62 × w. 95 cm, scale 1947264 (https://www. davidrumsey.com/luna/servlet/detail/RUMSEY 8 1 233539 5509641:South-Africa-delineated-fromvariou?sort=Pub_List_No_InitialSort\%2CPub_Date\%2CPub_List_No\%2CSeries_No\&qvq=q:south\%20 africa\%201815;sort:Pub_List_No_InitialSort\%2CPub_Date\%2CPub_List_No\%2CSeries_ No;lc:RUMSEY 8 1\& mi=0\&trs=12)

Figure 8: John Arrowsmith. Cape of Good Hope. London, 1836. h. 51 × w. 72 cm, scale 2350000 (https:// www.davidrumsey.com/luna/servlet/detail/RUMSEY 8 1 33872 1170024:Cape-of-Good-Hope?sort=Pub_List_No_InitialSort\%2CPub_Date\%2CPub_List_No\%2CSeries_No\&qvq=q:South\%20 africa\%201836;sort:Pub_List_No_InitialSort\%2CPub_Date\%2CPub_List_No\%2CSeries_ No;lc:RUMSEY 8 1\&mi=0\&trs $=60$ )

Figure 9: Re-enactment of Retief's visit to Dingane. Centenary celebrations. 1938 (courtesy of Museum Africa; photo the authors)

Figure 10: Franz Soff and Anton van Wouw. Vrouemonument, Bloemfontein. 1913 (photo the authors)

Figure 11: Founding members of the Afrikaner Broederbond with H.J. Klopper seated second from left. 1918 (https:// commons.wikimedia.org/wiki/File:Broederbond.jpg)

Figure 12: Bloukrans monument, Chieveley. 1897 (photo the authors)

Figure 13: Memorial to Retief and his men, uMgungundlovu. 1922 (photo the authors)

Figure 14: Voortrekker Museum, uMsunduzi Museum incorporating the Voortrekker Complex, Pietermaritzburg. 1915 (photo the authors)

Figure 15: Participants at first meeting of Voortrekker Monument committee, later called SVK (Volksblad 4.4.1931 courtesy of NARSSA, Engelenburg 140/3/14)

Figure 16: Jansen with members of the SVK. c. 1936. From left to right. Front: Senator F.S. Malan (government representative), Ernest George Jansen (chair), J.J. Scheepers (secretary until 1946). Back: Ivanhoe Makepeace Lombard (treasurer), B.H.J. van Rensburg (director of War Museum of Boer Republics), M.C. Booysen (school inspector), Gerard Moerdyk (architect) (photo courtesy of Kirchhoff files)

Figure 17: Mrs Martha Mabel Jansen with other members of first executive committee of Federation of Afrikaans Cultural Association (FAK), including I.M. Lombard behind her. 1929 (https://en.wikipedia.org/wiki/Federasie_ van_Afrikaanse_Kultuurvereniginge)

Figure 18: G.S. Preller (left) and S.P. Engelbrecht (right), members of Historiese Komitee, SVK (Left: https://commons.wikimedia.org/wiki/File:Gustav_Preller.jpg - Right: photo courtesy of Nederduitsch Hervormde Kerk archives photo collection)

Figure 19: Frans Vredenrijk Engelenburg, senior SVK member (by Frans Oerder - Feesalbum 1909-59, PD-SA; https://af.wikipedia.org/w/index.php?curid=62858)

Figure 20: M.C. Botha, secretary of SVK, 1946-68 (photo Dagbreek se speciale Monument, undated; courtesy of UP Archives, Moerdyk files)

Figure 21: Complete bilingual set of Voortrekker Monument stamps, overprinted S.W.A. (South West Africa). 1933-36 (photo courtesy of roydinsdaleebay@aol.com)

Figure 22: W.H. Coetzer. Voortrekker centenary stamps and souvenir cover brochure, 17.12.1938, sent to SVK chairman Jansen (courtesy of ARCA PV94 1/75/1/9; photo the authors)

Figure 23: W.H. Coetzer. Inauguration stamps on a Robstampco souvenir envelope sent to Australia. 16.12.1949 (http://pictures.auktionen-gaertner.de/auction/2144/622144-000002.jpg) 
Figure 24: Advertisement for a fundraising performance by the Stellenbosch Boer-orkes (courtesy of HF Archives VTM [old numbering] B10; photo the authors)

Figure 25: The special subcommittee of SVK that visited possible sites for the Monument (Volksblad 22.7.1936; courtesy of UP Archives, Moerdyk files MDK 0350T)

Figure 26: Photomontage of the Voortrekker Monument on the chosen Pretoria site (The Star 9.10.1936; courtesy of UP Archives, Moerdyk files)

Figure 27: Aerial view from north-east of Voortrekker Monument on Monumentkoppie with amphitheatre in foreground. December 1949 (courtesy of HF Archives F 39.6.6 k)

Figure 28: Descendants of Voortrekker leaders, Mesdames D.P. Ackerman, J.C. Muller and G.S. Preller, who laid Monument's foundation stone. 16 December 1938 (photo courtesy of Unisa Archives)

Figure 29: Fictitious representation of laying the Voortrekker Monument's foundation stone, published two days ahead of the event (Daily Express, 14.12.1938, p.1; courtesy of UP Archives, Moerdyk files)

Figure 30: Laying of the Voortrekker Monument foundation stone on 16 December 1938 (photo courtesy of Unisa Archives)

Figure 31: Routes of ossewatrek for the centenary celebrations. 1938 (Duvenage 1988, opp. title page)

Figure 32: Six 'Hooftrek' wagons at Winburg. 1938 (photo Fray; Mostert 1940, 45)

Figure 33: The over size post wagon Hendrik Potgieter. 1938 (Mostert 1940, 43)

Figure 34: Traces of the hooves of oxen and wheels of Andries Pretorius wagon recorded in cement on University of Pretoria campus, signed by Gerard Moerdyk. 1938. See footnote 569 (photo the authors)

Figure 35: Women in Voortrekker dress. Centenary ossewatrek. 1938 (https://upload.wikimedia.org/wikipedia/ commons/4/44/Voortrekker-1938_\%282\%29.jpg)

Figure 36: Bearded Boer on Piet Retief wagon at Mooimeisiefontein. Centenary ossewatrek. 24 September 1938 (https://resolver.kb.nl/resolve?urn=urn:gvn:ZAH01:100000132)

Figure 37: Gerard Moerdyk with Drawing 3. Cross-section of Voortrekker Monument (photo courtesy of HF Archives F 39.1.54 k)

Figure 38: Anton van Wouw's studio, Doornfontein. Small-size copy of Borghese Warrior (far right), photograph of 'Runner' from Herculaneum (on the wall). c. 1933 (photo courtesy of UP Archives, Van Wouw files)

Figure 39: Coert Steynberg. Design for Voortrekker Monument. 1935. Pencil, $22.8 \times 17.7 \mathrm{~cm}$ (photo courtesy of HF Archives SVK vol. 18 file 13.3.1)

Figure 40: Gerard Moerdyk. Early design for Voortrekker Monument. Undated (Fisher and Clarke 2010, 156 fig. 8)

Figure 41: Great Zimbabwe ruins, tower. 11th-15th century (https://i.pinimg.com/originals/9a/e4/c5/9ae4c5da988 4422a826fd886faa3db6b.jpg)

Figure 42: Columns of the Karnak temple at Luxor, photograph in Moerdyk's possession (photo courtesy of UP Archives, Moerdyk files MDK 0015V)

Figure 43: Gerard Moerdyk. Early design for Voortrekker Monument. 1936 (Die Vaderland 10.1.1936, 7; courtesy of ARCA and Free State Provincial Archives Repository Bloemfontein)

Figure 44: A.B. Hangartner. Transformer building, Kakamas. 1914 (photo courtesy of ID 160520746 @ dpreezg, depositphotos.com)

Figure 45: Gordon Leith. Voortrekker Gedenksaal (Memorial Hall), Pretoria. c. 1927. Not extant (Tully 1932)

Figure 46: Anton van Wouw. Kruger Monument, Church Square, Pretoria. 1899 (photo the authors)

Figure 47: Anton van Wouw. Figures and reliefs, detail of Vrouemonument, Bloemfontein. 1912. Bronze (photo the authors)

Figure 48: Superimposed Vrouemonument on Voortrekker Monument (Die Volksblad 12.12.1948; courtesy of UP Archives, Moerdyk files)

Figure 49: Anton van Wouw. Voortrekker mother and children. 1939. Bronze, $4.1 \mathrm{~m}$ (photo the authors)

Figure 50: Gerard Moerdyk. Elevation of Voortrekker Monument. 1936 (Die Volkstem 11.9.1936; courtesy of UP Archives, Moerdyk files MDK 0505T)

Figure 51: Gerard Moerdyk. Drawing 1, cross-section of Voortrekker Monument. 1936 (Die Volkstem 11.9.1936; courtesy of UP Archives, Moerdyk files MDK 0505T)

Figure 52: Gerard Moerdyk. Drawing 2, cross-section of Voortrekker Monument. 1936 (Die Vaderland 10.12.1936; courtesy of Aletta Steenkamp)

Figure 53a: Gerard Moerdyk. Drawing 3, cross-section of Voortrekker Monument. 1938 (Pretoria News 13.12.1938; courtesy of UP Archives, Moerdyk files)

Figure 53b: Gerard Moerdyk. Close-up of frieze in Drawing 3, cross-section of Voortrekker Monument. 1938. Detail of fig. 37 (photo courtesy of HF Archives F 39.1.54 k)

Figure 54a: Gerard Moerdyk. Drawing 4, cross-section of Voortrekker Monument. 1938 (courtesy of HF Archives F 39.1.35 k; photo Alan Yates)

Figure 54b: Gerard Moerdyk. Close-up of frieze in Drawing 4, cross-section of Voortrekker Monument. 1938 Detail of fig. $54 a$ 
Figure 55: Anton van Wouw. Armature for full-size clay Voortrekker Mother and Children. 1938 (photo courtesy of UP Archives, Van Wouw files)

Figure 56: Reconstruction of Mausoleum of Halicarnassus. c. 350 BC (Krischen 1938, pl. 37)

Figure 57: Great Altar from Pergamon, 2nd century BC. Marble, w. $36.8 \times 1.34 .2 \times$ h. c. 10 m. Pergamonmuseum, Berlin, early 1930s (photocourtesy of Museum für Abgüsse Klassischer Bildwerke Munich, photo archive 44734)

Figure 58: Anton van Wouw. Central and right section of frieze of Johannesburg Railway Station building. 1932. Cement (photo courtesy of UP Archives, Van Wouw files)

Figure 59: Anton van Wouw. Relief depicting departure of Piet Retief. 1933. Plaster (Die Vaderland 26.8.1933; courtesy of UP Archives, Van Wouw files)

Figure 60: Anton van Wouw. Centenary relief plaques presented to schools. 1938. Plaster (top) and ceramic (bottom) (courtesy of UP museum; photos the authors)

Figure 61: Louw \& Louw with F.M. Glennie. Old Mutual building, Cape Town. 1940 (South African Architect, January 1940).

Figure 62: Ivan Mitford-Barberton. Order of scenes in frieze of Old Mutual building, Cape Town. 1935-40. Granite, $112.8 \times 1.6 \mathrm{~m}$ (the authors drawing Janet Alexander)

Figure 63: Ivan Mitford-Barberton. 1837 Voortrekkers on the Great Trek, Old Mutual building, Cape Town. 1935-40 (photos the authors)

Figure 64: Advertisement for Old Mutual. c. 1950? (unknown origin)

Figure 65: Anton van Wouw working on clay model for The hammer worker. 1911 (photo courtesy of Van Wouw House Collection)

Figure 66: Gerard Moerdyk. 1913 (Vermeulen 1999, 56)

Figure 67: Gordon Leith helps to build armature in Rome for Van Wouw's Women with dead child for Vrouemonument, Bloemfontein. c. 1912 (photo courtesy of UP Archives, Van Wouw files)

Figure 68: Anton van Wouw. Women with dead child. Vrouemonument, Bloemfontein. 1913. Bronze, h. c. 4 m (photo the authors)

Figure 69: Table of proposals (the authors)

Figure 70: 'Voorstelle', first of the proposal documents outlining topics for the historical frieze. 1934? (courtesy of NARSSA Engelenburg 140/3/14, pp.112-113)

Figure 71: Jan Juta. The Great Trek. 1934. Oil on canvas. South Africa House, London (Freschi 2005, 26 fig. 11).

Figure 72: Jan Juta. Settlers presenting a Bible to Jacobus Uys. 1938. Oil on canvas, c. $3.35 \times 9.14 \mathrm{~m}$. Pretoria City Hall (courtesy of City of Tshwane; photo Helenus Kruger)

Figure 73: J.H. Amshewitz. Voorwaarts (Onward). 1937. Oil, $3.5 \times 3$ m. Pretoria City Hall (courtesy of City of Tshwane; photo Helenus Kruger)

Figure 74: Gerard Moerdyk. Model of Voortrekker Monument for Empire Exhibition, Johannesburg, 15 September 1936 to 15 January 1937 (https:// resolver.kb.nl/resolve?urn=urn:gvn:ZAH01:100002179)

Figure 75: Frikkie Kruger. Piet Retief, one of the corner figures at Voortrekker Monument. 1951. Granite, h. 5.5 m (photo the authors)

Figure 76: Bruno Schmitz et al. Völkerschlachtdenkmal, Leipzig. 1913. Steel and concrete with granite facing. h. $91 \mathrm{~m}$, plinth $70 \times 80 \mathrm{~m}$ (photo courtesy of Alamy G0GD80)

Figure 77: Gerard Moerdyk. Voortrekker Monument. Late 1949 (photo courtesy of Unisa, Van Schaik album)

Figure 78: Charles Bruce Dellit. ANZAC War Memorial, Sydney. 1934 (photo courtesy of Alamy R58TNH)

Figure 79: Shrine of Scottish War Memorial, Edinburgh Castle, with reliefs at eye level. Sculptor Gertrude Alice Meredith Williams. 1920s (https://cdn.shopify.com/s/files/1/0090/8453/4899/products/1-Scottish_War_ Memorial_Edinburgh_Castle_RPPC_2048x.jpg?v=1547148996)

Figure 80: Parthenon frieze in the Elgin Room, British Museum, London (photo courtesy of ID 17172158 @ Peter Lovás, dreamstime.com)

Figure 81: They built a nation. Scenes from the film, the largest being the Battle of Blood River. 1938 (Daily Express 13.12.1938; courtesy of National Library, Cape Town)

Figure 82: Scene of the Vow to God taken by a group of trekkers in the $1938 \mathrm{film}$, They built a nation (right) compared to the 1949 The Vow in the marble frieze (photo left Russell Scott; right https://en.m.wikipedia.org/wiki/ File:Cilliers-gelofte,_1938-film,_Die_bou_van_\%27n_nasie.jpg)

Figure 83: Gerard Moerdyk. 'The Altar of Afrikanerdom'. 1938 (Mostert 1940, colour plate following p.813)

Figure 84: Great Zimbabwe, section of outside wall with zig-zag band. 11th-15th century (photo I. E. Grady)

Figure 85: Section of laager of 64 Boer wagons surrounding Voortrekker Monument. 1949 (photo courtesy of HF Archives F 39.1.50 k)

Figure 86: René Shapshak. Frieze of Monument High School, Krugersdorp (Die Vaderland 2.7.1935; courtesy of UP Archives, Moerdyk files MDK 02307)

Figure 87: Gerard Moerdyk. Merensky Library, University of Pretoria. 1938 (photo the authors)

Figure 88: Gerard Moerdyk. Layout of panels for Voortrekker Monument frieze, with annotations probably by Jansen. Early 1937 ? (courtesy of ARCA PV94 1/75/1/9 photo the authors) 
Figure 89: E.G. Jansen? Sketch of Voortrekker Monument plan on the back of fig. 88. Early 1937? (courtesy of ARCA

PV94 1/75/1/9; photo the authors)

Figure 90: Authors' annotated version of Moerdyk's layout of panels (fig. 88)

Figure 91: Authors' annotated version of sketch of Voortrekker Monument plan (fig. 89)

Figure 92: List of topics proposed by Jansen to Minister of Interior, 19 January 1937 (the authors)

Figure 93: W.H. Coetzer. 'Painter of the Voortrek' (Dagbreek Tydskrif-bylaag, Commemoration edition, 4 December 1949; courtesy of UP Archives, Moerdyk files)

Figure 94: W.H. Coetzer. Uitspanning by Thaba 'Nchu (Outspan at Thaba 'Nchu). Stitched by H. Rossouw; one of fifteen tapestry scenes of the Great Trek for Voortrekker Monument. 1952-60. Wool, $80 \times 152 \mathrm{~cm}$ (courtesy of VTM Museum VTM 0001/14; photo Russell Scott)

Figure 95: W.H. Coetzer. The dusty shelf. 1930 . Oil on canvas, $49.5 \times 61 \mathrm{~cm}$ (photo courtesy of Johannesburg Art Gallery)

Figure 96: W.H. Coetzer. Vegkop - 16 Oktober 1836. Pencil drawing, $25.4 \times 38.1 \mathrm{~cm}$ (Coetzer 1947, 106)

Figure 97: W.H. Coetzer. Voortrekkers bo-op die Drakensberg (Voortrekkers atop the Drakensberg). Undated. Oil, c. $120 \times 180 \mathrm{~cm}$ (courtesy of DNMCH DHK 5533; photo Helenus Kruger, City of Tshwane)

Figure 98: W.H. Coetzer. First visual narrative of the Great Trek in twenty-two drawings (three extant in Gestetner reproductions only). 1937 (the authors)

Figure 99: Concordance of Coetzer drawings and reproductions (the authors)

Figure 100: W.H. Coetzer. Reproduction of first drawing for Return June 1937 (courtesy of ARCA PV94/1/75/5/1; photo the authors)

Figure 101: W.H. Coetzer. ‘Terugtog oor Drakensberg’. After September 1937. Pencil, 13.3 × 30.4 cm, image size. Revised first drawing (photo courtesy of Museum Africa, no. 66/2194Q)

Figure 102: W.H. Coetzer. Reproduction of first drawing for Departure, June 1937 (courtesy of PV94 1/75/5/1 photo the authors)

Figure 103: W.H. Coetzer, 'Uittog uit Kaapland'. After September 1937. Pencil, $13.3 \times 61.2 \mathrm{~cm}$, image size. Revised first drawing (photo courtesy of Museum Africa, no. 66/2194U)

Figure 104: W.H. Coetzer. New drawing 'Trichardt Zoutpansberg'. After September 1937. Pencil, $13.4 \times 15.3 \mathrm{~cm}$, image size (photo courtesy of Museum Africa, no. 66/2194A)

Figure 105: W.H. Coetzer. Reproduction of first drawing for Soutpansberg. June 1937 (courtesy of ARCA PV94 1/75/5/1; photo the authors)

Figure 106: Hennie Potgieter. Rejected maquette for Soutpansberg. 1942-43. Plaster, $76.5 \times 89.8 \times 8.6 \mathrm{~cm}$ (courtesy of VTM Museum VTM 2184/1-28; photo Russell Scott)

Figure 107: Hennie Potgieter. New maquette for Soutpansberg. 1942-43. Plaster, $78.3 \times 86.6 \times 8 \mathrm{~cm}$ (courtesy of VTM Museum VTM 2184/1-28; photo Russell Scott)

Figure 108: W.H. Coetzer. Reproduction of drawing for Allegory (courtesy of ARCA PV94 1/75/5/1 photo the authors)

Figure 109: W.H. Coetzer. Reconciliation of Pretorius and Potgieter. Pre-1937 (Nathan 1937, opp. p.340)

Figure 110: W.H. Coetzer. Reproduction of first drawing for Arrival. June 1937 (courtesy of ARCA PV94 1/75/5/1; photo the authors)

Figure 111: Advertisement for Preller’s film De Voortrekkers. 1916 (http://www.villonfilms.ca/wp-content/uploads/ Voortrekkers.jpg)

Figure 112: W.H. Coetzer. Voortrekkerkappies. Pre-1947. Pencil, $35.5 \times 38 \mathrm{~cm}$ (Coetzer 1947, fig. opp. p.27; photo courtesy of Unisa Archives)

Figure 113: W.H. Coetzer. 'Die Dingaan-Retief Traktaat' (The Dingane-Retief treaty). Late 1937-38? Monochrome oil on board, $27.3 \times 31 \mathrm{~cm}$ (courtesy of DNMCH, OHG 897; photo the authors)

Figure 114: Interior of Harmony Hall, Pretoria. Sculptors at work on Departure, 1942 (photo courtesy of HF Archives $\mathrm{F} 39.10 .7 \mathrm{k}$ )

Figure 115: The four sculptors at Harmony Hall: Peter Kirchhoff, Laurika Postma, Frikkie Kruger and Hennie Potgieter in his working smock (photo courtesy of Kirchhoff files)

Figure 116: Werner Kirchhoff, son of Peter Kirchhoff, at Harmony Hall, about to set out on his first day cycling to Pretoria Boys High School. 1943 (photo courtesy of Kirchhoff files)

Figure 117: Peter Kirchhoff in the 1930s (photo courtesy of Kirchhoff files)

Figure 118: Peter Kirchhoff at work on the relief tondos at Johannesburg Library. 1934 (courtesy of Kirchhoff files; photo Anna-Maria Kirchhoff)

Figure 119: Frikkie Kruger. The artist at Harmony Hall with full-scale model of wagon for laager around Voortrekker Monument. 1948. Clay, h. $2.7 \times$ w. 4.6 m. (photo courtesy of HF Archives F 39.10.8 k)

Figure 120: Frikkie Kruger. Bust of Paul Kruger. 1940s? Plaster (photo Anna-Maria Kirchhoff)

Figure 121: Gerard Moerdyk and Frikkie Kruger. Anglo-Boer War Memorial erected in Middelburg for the centennial. 1938 (photo Roger Fisher; https://www.artefacts.co.za/main/Buildings/bldg_images. php?bldgid=13440\#352088)

Figure 122: Laurika Postma in her studio in Bloemfontein. c. 1940 (courtesy of UP Archives, Postma Files) 
Figure 123: Laurika Postma. Vooruit. 1940. Bronze, h. 1.56m. Christelike en Nasionale Meisieskool Oranje, Bloemfontein (photo Gerhardus Bosch)

Figure 124: Hennie Potgieter. Early 1950s (photo courtesy of HF Archives F 19.1.4 k)

Figure 125: Hennie Potgieter. Buffalo over entrance to Voortrekker Monument. 1941. Granite (photo the authors)

Figure 126: Deutsche Turn Halle (German Gymnastic Club). c. 1910. Later Harmony Hall (Harmoniesaal), 137 Gerard Moerdyk Street, Pretoria (photo courtesy of Tshwane University of Technology, Faculty of Arts, Pretoria)

Figure 127: Laurika Postma. Arrival. 1942-43. Plaster maquette on an easel in Harmony Hall (photo courtesy of Kirchhoff files)

Figure 128: Models posing for Women spur men on in the yard at Harmony Hall. 1942? (photo courtesy of Kirchhoff files)

Figure 129: Women spur men on. 1943-45. Clay. Full-scale relief (courtesy of UP Archives; photo Alan Yates)

Figure 130: Short and full titles of the scenes for the frieze, with initials of the artists who designed them

Figure 131: W.H. Coetzer. 'Bloed Rivier'. After September 1937. Pencil, $13.3 \times 23 \mathrm{~cm}$, image size. Revised first sketch (photo courtesy of Museum Africa, no. 66/2194R)

Figure 132: Peter Kirchhoff. Blood River. 1942-43. Plaster, $79 \times 147 \mathrm{~cm}$. Damaged maquette (courtesy of VTM Museum VTM 2184/1-28; photo Russell Scott)

Figure 133: Hennie Potgieter. Kapain. 1942-43. Plaster, $77 \times 152.7 \mathrm{~cm}$. Maquette (courtesy of VTM Museum VTM 2184/1-28; photo Russell Scott)

Figure 134: Peter Kirchhoff. Abandoned maquette 'Vendusie' (Auction), based on left-hand section of Coetzer's sketch for Departure. Plaster, h. $78 \times$ w. $89.7 \times$ d. $8.2 \mathrm{~cm}$ (courtesy of VTM Museum VTM 2184/1-28; photo Russell Scott)

Figure 135: W.H. Coetzer. Left-hand section of reproduction of first sketch for Departure, detail of fig. 102 (courtesy of ARCA PV 94 1/75/5/1)

Figure 136: Marthinus Oosthuizen. 1943-45. Clay. Full-scale relief (Pillman 1984, 52; photo Alan Yates)

Figure 137: Dirkie Uys. 1943-45. Clay. Full-scale relief (Pillman 1984, 48-49; photo Alan Yates)

Figure 138: Frikkie Kruger. Clay maquette of Return on an easel at Harmony Hall. 1942-43 (photo courtesy of Kirchhoff files)

Figure 139: Frikkie Kruger working on first maquette for Treaty. 1942-43. Clay (courtesy of VTM Museum; photo the authors)

Figure 140: Frikkie Kruger. Second maquette for Treaty. 1942-43. Plaster, $77.5 \times 76.7 \mathrm{~cm}$ (courtesy of VTM Museum VTM 2184/1-28; photo Russell Scott)

Figure 141: The plaster maquettes (courtesy of VTM Museum VTM 2184/1-28; photos Russell Scott)

Figure 142: Laurika Postma. Marthinus Oosthuizen. 1942-43. Plaster, h. $77.2 \times$ w. $83 \times$ d. $10 \mathrm{~cm}$. Maquette (courtesy of VTM Museum VTM 2184/1-28; photo Russell Scott)

Figure 143: Model for collapsing Zulu in Marthinus Oosthuizen, in the grounds of Harmony Hall. 1943-45. (Pillman 1984, 53)

Figure 144: Hennie Potgieter. First maquette for Delagoa Bay. 1942-43. Plaster, h. $77 \times$ w. $76.5 \times$ d. $8 \mathrm{~cm}$ (courtesy of VTM Museum VTM 2184/1-28; photo Russell Scott)

Figure 145: Hennie Potgieter. Second maquette for Delagoa Bay. 1942-43. Plaster, h. $76 \times$ w. $76.6 \times$ d. $8 \mathrm{~cm}$ (courtesy of VTM Museum VTM 2184/1-28; photo Russell Scott)

Figure 146: Hennie Potgieter. First maquette for Blydevooruitsig. 1942-43. Plaster, h. 77 × w. $89.7 \times$ d. $10.3 \mathrm{~cm}$ (courtesy of VTM Museum VTM 2184/1-28; photo Russell Scott)

Figure 147: Hennie Potgieter. Second maquette for Blydevooruitsig. 1942-43. Plaster, h. $76 \times$ w. $92.2 \times$ d. 8 cm (courtesy of VTM Museum VTM 2184/1-28; photo Russell Scott)

Figure 148: Group of artefacts in Departure. Marble, detail of fig. 286 (photo Russell Scott)

Figure 149: 'Harmony Hall, Vera [Kirchhoff], 1942, Voortrekker maiden'. Album page with model posing for Saailaer (photos courtesy of Kirchhoff files)

Figure 150: Peter Kirchhoff. Saailaer. 1942-43. Plaster, h. 77 × w. 142.7 cm. Maquette (courtesy of VTM Museum VTM 2184/1-28; photo Russell Scott)

Figure 151: Models wearing Voortrekker dresses staged like sculptures on plinths, Harmony Hall. c. 1942-44 Pretoria (photo courtesy of Kirchhoff files)

Figure 152: Werner Kirchhoff (see fig. 116) posed for: young Paul Kruger (portrait Louis Jacobs) in Vegkop (fig. 290); young hero in Dirkie Uys (fig. 301); surveyor (portrait H. Ahlers) in Church of the Vow (fig. 307) (photos Russell Scott)

Figure 153: Martso Strydom posed for three scenes - Above: Englishwoman on left in Presentation (she is photographed alongside it, 54 years later; courtesy of HF Archives F 39.10.10 k); Debora (portrait Irma Moerdyk) in Debora Retief (detail of fig. 295; photo Russell Scott). - Below: bending woman (portrait Babette Vaandrager) and turning woman in Vegkop (details of fig. 290; photos Russell Scott)

Figure 154: Stephanie Joubert, model for girl with doll in Debora Retief (Barnard 1974, 82)

Figure 155: Girl with doll in Debora Retief. Marble, detail of fig. 295 (photo Russell Scott) 
Figure 156: Erasmus Smit, photo. c. 1850? (photo courtesy of uMsunduzi Museum Collection)

Figure 157: Portrait of Erasmus Smit in Inauguration. Marble, detail of fig. 291 (photo Russell Scott)

Figure 158: Actor playing Piet Retief in Preller's film Die Voortrekkers. 1918 (Preller, Retief 1930, frontispiece)

Figure 159: Portrait of Retief in Treaty. Marble, detail of fig. 297 (photo Russell Scott)

Figure 160: Hendrik Ploeger working on Descent. Detail of fig. 175 (photo courtesy of Kirchhoff files)

Figure 161: Studio carpenter Hendrik Ploeger as bystander in Inauguration. Marble, detail of fig. 291 (photo Russell Scott)

Figure 162: Studio assistant Piet Malotho as the Rolong chief Moroka, framed by his men in Negotiation. Marble, detail of fig. 293 (photo Russell Scott)

Figure 163: Elderly woman 'Oumatjie Stoffberg' in Presentation. Marble, detail of fig. 287 (photo Russell Scott)

Figure 164: Lea Spanno, model for Teresa Viglione (Barnard 1974, 82)

Figure 165: Portrait of Italian trader on horseback in Teresa Viglione. Marble, detail of fig. 300 (photo Russell Scott)

Figure 166: Mother and child in Inauguration. Details of maquette and full-size clay relief (photos left Russell Scott, right Alan Yates)

Figure 167: Couple on the left in Women spur men on. Details of maquette and full-scale clay (photos left Russell Scott, right Alan Yates)

Figure 168: Dingane and his followers in Treaty. Maquette and marble, detail of fig. 297 (photos above the authors, below Russell Scott)

Figure 169: Frikkie Kruger. Negotiation. Maquette photographed in different light and from different angles (courtesy of VTM Museum VTM 2184/1-28; photos left the authors, right Russell Scott)

Figure 170: Laurika Postma. Debora Retief. Maquette photographed in different light and from different angles (courtesy of VTM Museum VTM 2184/1-28; photos left the authors, right Russell Scott)

Figure 171: Harmony Hall view showing board supporting Departure with scaffold in front and lifting pulley above (detail of fig. 114)

Figure 172: Right side of Departure in progress in Harmony Hall, c. 1943, with, left to right, sculptors Frikkie Kruger (on scaffolding), Laurika Postma, Hennie Potgieter and Peter Kirchhoff (photo courtesy of Kirchhoff files)

Figure 173: Harmony Hall view with mock-up of the frieze made up of one-third-size maquettes (detail of fig. 114)

Figure 174: Blue and red surface markings in Arrival. Detail of maquette (courtesy of VTM Museum VTM 2184/1-28; photo Russell Scott)

Figure 175: Hendrik Ploeger applying clay on full-size armature for Descent (photo courtesy of Kirchhoff files)

Figure 176: Frikkie Kruger(?) at work on Murder of Retief, west side of south frieze (photo courtesy of Kirchhoff files)

Figure 177: Hennie Potgieter(?) at work on Bloukrans, west side of south frieze (photo courtesy of Kirchhoff files)

Figure 178: Armature for east side of the south frieze: Descent alongside Treaty (photo courtesy of Kirchhoff files)

Figure 179: Armature for east side of south frieze: Treaty between Descent and left-hand section of Murder of Retief (photo courtesy of Kirchhoff files)

Figure 180: Hennie Potgieter. Presentation. 1942-43. Plaster, h. $79 \times$ w. $76 \times$ d. 10.4 cm. Maquette (courtesy of VTM Museum VTM 2184/1-28; photo Russell Scott)

Figure 181: Presentation. 1943-45. Clay. Full-scale relief (courtesy of The Joyce Newton Thompson Collection, UCT Libraries, Special Collections BC643, A4.123-39; photo Alan Yates)

Figure 182: Vegkop showing framing figures juxtaposed with figures from the adjacent scenes (courtesy of VTM; photo Russell Scott)

Figure 183: Photograph of completed plaster panels mounted in the Hall of Heroes, Die Vaderland 26.2.1945; with detail of Murder of Retief and Bloukrans (photo courtesy of National Library, Cape Town)

Figure 184: Murder of Retief. 1943-45. Clay, full-size relief (Potgieter 1987, 24; photo Alan Yates, stitched)

Figure 185: Alan Yates photograph of north half of east frieze and reverse with annotations (courtesy of Romanelli files; photo the authors)

Figure 186: Alan Yates photograph of south half of east frieze and reverse with annotations (courtesy of Romanelli files; photo the authors)

Figure 187: Alan Yates photograph of west half of south frieze and reverse with annotations (courtesy of Romanelli files; photo the authors)

Figure 188: Peter Kirchhoff with Gerard Moerdyk and his portrait bust at Harmony Hall. c. 1944-45. Plaster cast of section of Vegkop behind (photo courtesy of Kirchhoff files)

Figure 189: Plaster casts of Kapain and Negotiation in situ in Monument. Corner panel of Blydevooruitsig already removed (Die Vaderland 10.9.1947; courtesy of UP Archives, Moerdyk files)

Figure 190: Inauguration; full-scale clay relief showing seated woman with small boy (courtesy of Romanelli files; photo Alan Yates, stitched by the authors)

Figure 191: Inauguration. Showing seated woman with swaddled baby. 1949. Marble (courtesy of VTM; photo Russell Scott)

Figure 192: Newspaper article 'Gruesome friezes in Voortrekker Monument' with illustration of Bloukrans (Rand Daily Mail 15.2.1945; courtesy of NARSSA, BNS 146/73/3) 
Figure 193: Motif of baby being dashed to death in W.H. Coetzer, 'Bloukrans Moord' sketch, 1937, and Bloukrans full-scale clay relief, 1943-45 (photo above courtesy of Museum Africa, below courtesy of Kirchhoff files; photo Alan Yates)

Figure 194: Section cut from the full-scale plaster relief of Bloukrans with baby being dashed to death. 1945-47 (VTM Museum; photo Russell Scott)

Figure 195: New maquette with Zulu torching a wagon in place of dashing baby to death. 1946-47. Plaster, h. $79 \times$ w. $83 \times$ d. $9 \mathrm{~cm}$. (courtesy of VTM Museum VTM 2184/1-28; photo Russell Scott)

Figure 196: Table of cuts of the plaster sections for the frieze

Figure 197: Romano Romanelli. Equestrian statue of Louis Botha. 1931. Bronze, cast by Vignali foundry, Florence (photo courtesy of Alamy D47KY7)

Figure 198: Romano Romanelli, Gerard Moerdyk, Laurika Postma, Hennie Potgieter and two Florentine sculptors at the Romanelli studio. c. 1948 (photo courtesy HF Archives F 39.10.9 k)

Figure 199: The Romanelli studio in 2013. 'Valkyrie' plaster model showing Giorgio Castriota Scanderbeg on horseback (photo the authors)

Figure 200: Querceta quarry near Forte dei Marmi, Italy (Pillman 1984, 56)

Figure 201: Marble panels ready for transportation. 1948 (courtesy of UP Archives, Postma files; photo N. Lughetti, Forte dei Marmi)

Figure 202: First page of Laurika Postma's letter to her sister Sophie, Florence 19.11.1948, describing difficulty of finding a passage back to South Africa (courtesy of UP Archives, Postma Folder 19; photo the authors)

Figure 203: Two diagonal breaks splitting the panel of Return in three. Marble, detail of fig. 311 (photo Russell Scott)

Figure 204: Panel transported up initial flight of steps at Voortrekker Monument (photo courtesy of Unisa Archives, Van Schaik album)

Figure 205: Ramp for transporting panels up to door of Voortrekker Monument (photo courtesy of Unisa Archives, Van Schaik album)

Figure 206: Equipment for installing frieze. West wall with The Vow, Church of the Vow and Saailaer, framing gap for Blood River. 1949 (unidentified newspaper clipping, courtesy of UP Archives, Moerdyk files MDK0491T)

Figure 207: Installation of Saailaer and Mpande, the former still in need of cleaning after transportation (photo courtesy of Unisa Archives, Van Schaik album)

Figure 208: Cornelius Pretorius installing Presentation (Die Vaderland 19.5.1949; courtesy of ARCA EG PV94 1/75/6/3)

Figure 209: Hennie Potgieter, Frikkie Kruger and unknown assistant in front of the installed panels for Debora Retief, Descent and Treaty (Dagbreek en Sondagnuus 30.10.1949)

Figure 210: Hennie Potgieter cleans Convention a month before inauguration (Rand Daily Mail 17.11.1949)

Figure 211: 'Voortrekkers clean the Monument the night before inauguration', in front of Treaty and Murder of Retief (Botha 1952, 267; photo Die Burger)

Figure 212: Interior view of Voortrekker Monument with gaps of missing panels, Bloukrans and Blood River. Late December 1949 (photo courtesy of HF Archives F 39.6.85 k)

Figure 213: Ground plan marking the five panels missing on 16 December 1849 (plan drawing Tobias Bitterer)

Figure 214: Prime Minister D.F. Malan delivers his address at inauguration of Voortrekker Monument (photo courtesy of HF Archives F 39.6.145 k)

Figure 215: Inauguration. Twelve Afrikaner girls and boys in Voortrekker costume officially open the Monument at a signal from Prime Minister Malan in the amphitheatre at noon on 16 December 1949 (photo courtesy HF Archives F 39.6.60 k)

Figure 216: The same ritual as in fig. 215 but seen from the Hall of Heroes, with Convention in place (left) but Departure missing (right). 16.12.1949 (Erlank, Thom and Rousseau 1950, 15; photo State Information Office, Pretoria)

Figure 217: Crowd waiting to enter the Monument on 16 December 1949 (photo courtesy of HF Archives F 39.6.153 k)

Figure 218: Gerard Moerdyk and Romano Romanelli at the Voortrekker Monument. December 1949 (photo courtesy of Kirchhoff files)

Figure 219: Moerdyk shows frieze to transport delegates, while Delagoa Bay and Vegkop are not mounted. 30.4.1950 (courtesy of UP Archives, Moerdyk files MDK 0504T)

Figure 220: Behind the scenes. Black workers providing 40000 bundles of firewood for the inauguration, 'to enable persons camping out at the Monument to prepare their own food ... 50 tons of firewood will be required' (courtesy of HF Archives F 39.6.46 k; photo City Council of Pretoria with cited text on back)

Figure 221: Black women cooking for visitors who camp at the inauguration site (photo Margaret Bourke-White for Life 16.1.1950; https://johnedwinmason.typepad.com/john_edwin_mason_photogra/2012/08/margaretbourke-white-south-africa-p1.html)

Figure 222: Black nanny looking after toddler at inauguration (detail of photo courtesy of Museum Africa)

Figure 223: 'Old Jacob', former coach driver to President Kruger, age 85, at inauguration of Voortrekker Monument (Bond 1949, unpaginated) 
Figure 224: Attic grave relief of two warriors. c. 420-410 BC. Marble, h. 1.8 m (Piraeus Museum; photo Hermann

Wagner; German Archaeological Institute, Athens, D-DAI-ATH-Grabrelief-0754_47891,01.jpg)

Figure 225: Rolong with contrapposto in Negotiation. Marble, detail of fig. 293 (photo Russell Scott)

Figure 226: Plants between legs of animals in Departure. Marble, detail of fig. 286 (photo Russell Scott)

Figure 227: Donatello, The Crucifixion of Christ c. 1460-90. Bronze, part of the Passion Pulpit made for San Lorenzo, Florence (photo courtesy of Zentralinstitut für Kunstgeschichte, Munich)

Figure 228: Andrea del Verrocchio, The beheading of St John the Baptist. c. 1460-80. Silver, part of altar decoration made by several artists for San Giovanni, Florence (Museo dell'Opera del Duomo; photo the authors)

Figure 229: Professor Bleeker and Laurika Postma in front, and further students behind, pose outside Munich's Academy of Fine Arts and equestrian statue of Pollux (Pillman 1984, 32)

Figure 230: Hildebrandt's 1907 monograph The problem of form (photo the authors)

Figure 231: Captain Gamitto and Portuguese soldier in Delagoa Bay. Detail of full-scale clay relief (photo Alan Yates)

Figure 232: Masked bodies and limbs in Departure, Descent and The Vow. Details of full-scale clay reliefs (photos Alan Yates)

Figure 233: Dying woman with suppressed breast in Bloukrans. Details of full-scale clay relief and marble (photos left Alan Yates; right detail of fig. 299, Russell Scott)

Figure 234: Women in Voortrekker dress with long-sleeved bodice and conical skirt; on right of Descent and Return. Marble, details of figs 296 and 311 (photos Russell Scott)

Figure 235: Hovering women with invisible feet in Debora Retief and Saailaer. Marble, details of figs 295 and 308 (photos Russell Scott)

Figure 236: Excessive folds. Pfeffer in Delagoa Bay and Boer riders in Kapain. Details of full-scale clay relief (photos Alan Yates)

Figure 237: Attacking Zulu with stiff apron in Bloukrans. Detail of full-scale clay relief (photo Alan Yates)

Figure 238: Stoic Boer is killed by Zulu in Murder of Retief. Marble, detail of fig. 298 (photo Russell Scott)

Figure 239: Ferocious Zulu kills Boer in Murder of Retief. Marble, detail of fig. 298 (photo Russell Scott)

Figure 240: Portrait of Moerdyk in Church of the Vow. Marble, detail of fig. 307 (photo Russell Scott)

Figure 241: Peter Kirchhoff with Gerard Moerdyk and his portrait bust at Harmony Hall. c. 1944-45 (photo courtesy of Kirchhoff files)

Figure 242: Position of scenes developed by Peter Kirchhoff, 1 Departure, 21 Blood River, 22 Church of the Vow, 23 Saailaer and 27 Convention (plan drawing Tobias Bitterer)

Figure 243: Procession of sheep in Departure. Marble, detail of fig. 286 (photo Russell Scott)

Figure 244: Bertel Thorvaldsen, procession of sheep in the Alexander frieze. 1822. Marble (courtesy of Thorvaldsens Museum A508, Copenhagen; photo Jakob Faurvig)

Figure 245: Georg Kolbe, Dancer and maiden of Heinrich Heine memorial, Frankfurt am Main. 1913. Bronze (https:// commons.wikimedia.org/wiki/File:Taunusanlage-heine-denkmal-2011-ffm-076.jpg)

Figure 246: Wilhelm Lehmbruck, Der Gestürzte (The fallen). 1915-16. Bronze, l. 2.36 m (Pinakothek der Moderne, Munich; photo Oliver Kurmis; https://commons.wikimedia.org/wiki/File:Wilhelm_Lehmbruck_-_Der_ Gest\%C3\%BCrzte.2.jpg)

Figure 247: Position of scenes developed by Frikkie Kruger, 8 Negotiation, 11 Descent, 12 Treaty, 13 Murder of Retief, 15 Teresa Viglione, 24 Mpande and 27 Return (plan drawing Tobias Bitterer)

Figure 248: Aloes and chicken coop in Return. Marble, details of fig. 311 (photos Russell Scott)

Figure 249: Plants amidst the slain Boers on top of kwaMatiwane in Murder of Retief. Marble, detail of fig. 298 (photo Russell Scott)

Figure 250: Position of scenes developed by Laurika Postma, 10 Debora Retief, 14 Bloukrans, 16 Dirkie Uys, 17 Marthinus Oosthuizen, 18 Women spur men on, 19 Arrival, 20 The Vow, and 25 Death of Dingane (plan drawing Tobias Bitterer)

Figure 251: Milly Steger, Die Herbe (The austere). 1928. Bronze, 1.03 m (undated article in Kunst der Nation 1930s; courtesy of UP Archives, Postma Folder)

Figure 252: Boers listening to the covenant in The Vow. Marble (courtesy of VTM; photo Russell Scott)

Figure 253: Position of scenes developed by Hennie Potgieter, 2 Presentation, 3 Soutpansberg, 4 Delagoa Bay, 5 Vegkop, 6 Inauguration, 7 Kapain and 9 Blydevooruitsig (plan drawing Tobias Bitterer)

Figure 254: Confused limbs in Inauguration. Retief kneels in the foreground, his near leg disappearing behind seated woman. Detail of full-scale clay relief (photo Alan Yates)

Figure 255: Foreground, middle distance and background figures in Blydevooruitsig. Full-scale clay relief (photo Alan Yates)

Figure 256: Upright stance of Martha Trichardt in Delagoa Bay contradicts her collapse due to malaria. Marble, detail of fig. 289 (photo Russell Scott)

Figure 257: Spatial view from within the laager in Vegkop. Full-size clay relief (courtesy of Kirchhoff files; photo Alan Yates)

Figure 258: Close up composition in Kapain. Full-size clay relief (courtesy of Kirchhoff files; photo Alan Yates) 
Figure 259: Romano Romanelli, Gerard Moerdyk, Laurika Postma, Hennie Potgieter and two Florentine sculptors at the Romanelli studio. Full-size replications in plaster of lost clay panels in the background. c. 1948 (photo courtesy HF Archives F 39.10.9 k)

Figure 260: Romanelli's 'School of Sculpture' in Florence's Accademia with students copying life model in the background. 1951 (Accademia di Firenze 1984, 107)

Figure 261: Studio Romanelli, Borgo San Frediano 70, Florence. 2013 (photo the authors)

Figure 262: Undated self-portrait of Romano Romanelli (Accademia di Firenze 1984, 122)

Figure 263: Romano Romanelli, La giustizia di Traiano (The justice of Trajan) inside the Palazzo di Giustizia in Milan, left panel. Marble, $5 \times 5 \mathrm{~m}$ (Maulsby 2014, 317 fig. 3)

Figure 264: Portraits of Louis and Martha Trichardt in Soutpansberg. Marble, details of fig. 288 (photo Russell Scott)

Figure 265: Cut-off right shoulder but extant right hand in Women spur men on. Marble, details of fig. 303 (photos the authors)

Figure 266: Cut-off right shoulders but extant right hands in Church of the Vow. Marble, detail of fig. 307 (photo the authors)

Figure 267: Far hands of Boers holding guns without arms in Kapain. Marble, detail of fig. 292 (photo Russell Scott)

Figure 268: Thickened brims of women's kappies in Inauguration and Arrival. Marble, details of figs 291 and 304 (photos Russell Scott)

Figure 269: Oversized 'support' under right arm of shooting woman in Saailaer. Marble (Grobler 2001, 136)

Figure 270: Free-cut hand and lower end of Dordrecht Bible in Presentation. Details of full-scale clay relief and marble (photos above Alan Yates; below detail of fig. 287, Russell Scott)

Figure 271: Simplified beard, clothing folds and hands of dying father in Dirkie Uys. Details of full-scale clay relief and marble (photos above Alan Yates; below detail of fig. 301, Russell Scott)

Figure 272: Disfigured clerical collar of Rev. Erasmus Smit in Inauguration. Marble, detail of fig. 291 (photo Russell Scott)

Figure 273: Joints cutting through human and beast in Departure, Treaty and Return. Marble, details of figs 286, 297 and 311 (photos Russell Scott)

Figure 274: Florentine sculptor with hammer, long measuring rod and large T-square sitting next to Hennie Potgieter at the Romanelli studio to sculpt Presentation. The top left corner of full-size relief in plaster can be seen behind Moerdyk. c. 1948 (photo courtesy HF Archives F 39.10.9 k)

Figure 275: Border figure and framing veneer cut because of problems with measurement in Teresa Viglione. Details of full-scale clay relief and marble (photo left Alan Yates; right detail of fig. 300, Russell Scott)

Figure 276: Border figure and framing veneer cut because of problems with measurement in Convention. Details of full-scale clay relief and marble (photo left Alan Yates; right detail of fig. 312, Russell Scott)

Figure 277: Different tool traces and texture treatments around boy representing president-to-be Paul Kruger in Vegkop. Marble, detail of fig. 290 (photo Russell Scott)

Figure 278: Aloe in Return. Details of full-scale clay relief and marble (photos left Alan Yates; right detail of fig. 311, Russell Scott)

Figure 279: Debora Retief. Crisp rock structures in full-scale clay relief on left, muted in marble on right (photos left Alan Yates; right Russell Scott)

Figure 280: Wagon wheels in Departure. Details of full-scale clay relief and marble (photos above Alan Yates; below detail of fig. 286, Russell Scott)

Figure 281: Wagon wheels seen from an angle in Return. Details of full-scale clay relief and marble (photos left Alan Yates; right detail of fig. 311, Russell Scott)

Figure 282: Louis Trichardt in Delagoa Bay. Detail of full-scale clay relief (courtesy of Kirchhoff files; photo Alan Yates)

Figure 283: Louis Trichardt in Delagoa Bay. Marble, detail of fig. 289 (photo Russell Scott)

Figure 284: Boer women with idealised features in Departure and Saailaer. Marble, details of figs 286 and 308 (photos Russell Scott)

Figure 285: Different textures for skin and fabric in Martha Trichardt 's dress in Soutpansberg. Marble, detail of fig. 288 (photo Russell Scott)

Figure 286: Departure. 1950. Marble, w. 7.11 m (courtesy of VTM; photo Russell Scott)

Figure 287: Presentation. 1949. Marble, w. 2.4 m (courtesy of VTM; photo Russell Scott)

Figure 288: Soutpansberg. 1949. Marble, w. 2.4 m (courtesy of VTM; photo Russell Scott)

Figure 289: Delagoa Bay. 1950. Marble w. 2.88 m (courtesy of VTM; photo Russell Scott)

Figure 290: Vegkop. 1950. Marble, w. 4.56 m (courtesy of VTM; photo Russell Scott)

Figure 291: Inauguration. 1949. Marble, w. 2.82 m (courtesy of VTM; photo Russell Scott)

Figure 292: Kapain. 1949. Marble, w. 4.32 m (courtesy of VTM; photo Russell Scott)

Figure 293: Negotiation. 1949. Marble, w. 2.73 m (courtesy of VTM; photo Russell Scott)

Figure 294: Blydevooruitsig. 1949. Marble, w. 2.4 m (courtesy of VTM; photo Russell Scott)

Figure 295: Debora Retief. 1949. Marble, w. 2.4 m (courtesy of VTM; photo Russell Scott) 
Figure 296: Descent. 1949. Marble, w. 4.76 m (courtesy of VTM; photo Russell Scott) Figure 297: Treaty. 1949. Marble, w. 2.14 m (courtesy of VTM; photo Russell Scott) Figure 298: Murder of Retief. 1949. Marble, w. 3.7 m (courtesy of VTM; photo Russell Scott) Figure 299: Bloukrans. 1950. Marble, w. $4.61 \mathrm{~m}$ (courtesy of VTM; photo Russell Scott) Figure 300: Teresa Viglione. 1949. Marble, w. 2.07 m (courtesy of VTM; photo Russell Scott) Figure 301: Dirkie Uys. 1949. Marble, w. 2.4 m (courtesy of VTM; photo Russell Scott) Figure 302: Marthinus Oosthuizen. 1949. Marble, w. 2.4 m (courtesy of VTM; photo Russell Scott) Figure 303: Women spur men on. 1949. Marble, w. 2.25 m (courtesy of VTM; photo Russell Scott) Figure 304: Arrival. 1949. Marble, w. 2.34 m (courtesy of VTM; photo Russell Scott) Figure 305: The Vow. 1949. Marble, w. 2.28 m (courtesy of VTM; photo Russell Scott) Figure 306: Blood River. 1950. Marble, w. 4.29 m (courtesy of VTM; photo Russell Scott) Figure 307: Church of the Vow. 1949. Marble, w. 2.19 m (courtesy of VTM; photo Russell Scott) Figure 308: Saailaer. 1949. Marble, w. 4.01 m (courtesy of VTM; photo Russell Scott) Figure 309: Mpande. 1949. Marble, w. 2.4 m (courtesy of VTM; photo Russell Scott) Figure 310: Death of Dingane. 1949. Marble, w. 2.4 m (courtesy of VTM; photo Russell Scott) Figure 311: Return. 1949. Marble, w. 4.29 m (courtesy of VTM; photo Russell Scott) Figure 312: Convention. 1949. Marble, w. 2.82 m (courtesy of VTM; photo Russell Scott) Figure 313: Topics of Trajan's Column and Voortrekker Monument frieze: a comparison (the authors) Figure 314: Section of Trajan's Column, Rome. AD 106-13 (photo the authors)

Figure 315: Tour guide Godfrey Zahke explains the frieze to visitors from Rheinland-Pfalz Youth Orchestra, Germany (photo courtesy of VTM)

Figure 316: Scene from symbolic ossewatrek re-enactment for 1938 centenary (photo T. Hilton; https://www.flickr. com/photos/hilton-t/3932098536/)

Figure 317: W.H. Coetzer. 1938 commemorative medal with torch relay by Voortrekker boys and girls from Cape Town to Pretoria on the reverse (courtesy of VTM Museum VTM 1230/1-2; photo the authors)

Figure 318: Building of the Voortrekker Monument (courtesy of Kirchhoff files)

Figure 319: Moerdyk showing the frieze to members of the ATKV (Volkstem 10.9.1947; courtesy of UP Archives, Moerdyk collection MDK 497)

Figure 320: Black guard at high fence surrounding Voortrekker Monument (Rand Daily Mail 6.8.1947; courtesy of UP Archives, Moerdyk collection, 0469T)

Figure 321: Crowds at Voortrekker Monument for inauguration, December 1949 (The Illustrated London News 31.12.1949; courtesy of UCT Thompson, Newspaper clippings, 1938-50)

Figure 322: Volkspelers (folk dancers) in Voortrekker dress at inauguration in amphitheatre of Voortrekker Monument. 16 December 1949 (Botha 1952, 261)

Figure 323: Hans Hallen. Voortrekkermonument, Winburg. 9.11.1988 (https://www.boerenbrit.com/archives/15687/ dsc01030-2\#main)

Figure 324: Statue of Hendrik Verwoerd being removed from the front of administrative buildings, Bloemfontein. 9 September 1994 (http://www.aparchive.com/metadata/youtube/2cf6fca890e306669c7bcf99ef364282)

Figure 325: Statue of Danie Theron, formerly at Kimberley's Danie Theron Combat School, installed in 2002 at Fort Schanskop adjacent to Voortrekker Monument (photo the authors)

Figure 326: Hennie Potgieter. Getemde vryheid (Tamed freedom). 1962. Bronze. Installed outside Heritage Centre at Voortrekker Monument (photo courtesy of VTM)

Figure 327: Louis Eksteen. Quo vadis-triptiek. 1991. Linocut, each $18 \times 15 \mathrm{~cm}$ (courtesy of the artist; photo (C) Die Erfenisstigting; Voortrekker Monument 1838-1938, 62)

Figure 328: Penny Siopis. Design for ‘Myths, monuments, museums: New premises?' History Workshop, University of the Witwatersrand, Johannesburg. 1992 (Khan 1992, frontispiece; UCT Libraries, Special Collections)

Figure 329: Minister of Arts and Culture, Paul Mashatile, proclaiming the Voortrekker Monument a national heritage site. 16.3.2012 (courtesy of 2012Media24; foto24 Brendan Croft)

Figure 330: Freedom Park. Aerial view (photo courtesy of Graham Young; retrieved from a downed drone, owner unknown)

Figure 331: Freedom Park. Wall of Names (photo David Evans; www.cs.virginia.edu/ evans/pictures/za2010/0622_ freedom-park/)

Figure 332: Hector Pieterson Memorial, Soweto (https://image.jimcdn.com/app/cms/image/transf/ dimension=4096x4096:format=jpg/path/sef617628751e3ff6/image/i18a2a4da54b7db25/ version/1478599632/image.jpg)

Figure 333: Dingane. 'Long walk to freedom‘ at Groenkloof Nature Reserve, Pretoria. Painted bronze, life size (photo the authors)

Figure 334: André Prinsloo and Ruhan Janse van Vuuren. Nelson Mandela. 2013. Bronze, h. 9 m. Union Buildings, Pretoria (photo and copyright courtesy of Thomas Thomsen)

Figure 335: Coert Steynberg. Louis Botha. 1946. Bronze. Union Buildings, Pretoria (photo courtesy of Alamy ACT05P) 
Figure 336: David Goldblatt. The Voortrekker Monument and a Sunday service of the ultraconservative Afrikaanse Protestantse Kerk (Afrikaans Protestant Church) after a rally of right-wing Afrikaners who threatened war if South Africa became a non-racial democracy, Pretoria, Transvaal, 27 May 1990. 1990. Silver gelatin print on fibre-based paper. Edition of 10. The slogan reads ‘Build our own future' (photo courtesy the David Goldblatt Legacy Trust and Goodman Gallery)

Figure 337: Tokyo Sexwale, then premier of Gauteng province, at assegai gate of Voortrekker Monument (photo Sunday Times 15.12.1996)

Figure 338: Chinese tourists at Voortrekker Monument on Hug-a-Tourist Day (photo courtesy of VTM)

Figure 339: School children on a visit to Voortrekker Monument (photo courtesy of VTM)

Figure 340: Aerial view of Voortrekker Monument site, showing the extensive grounds, the amphitheatre, and Fort Schanskop beyond (photo courtesy of VTM)

Figure 341: Gedenktuin (Garden of Remembrance), Voortrekker Monument (photo courtesy of VTM)

Figure 342: Chapel, Voortrekker Monument (photo courtesy of VTM)

Figure 343: SADF Wall of Remembrance, Voortrekker Monument (photo the authors)

Figure 344: W.H. Coetzer. Souvenir bowl for 1938 centenary (private collection; photo the authors)

Figure 345: Souvenir spoon for 1938 centenary (private collection; photo the authors)

Figure 346: Leanie van der Vyver. Voortrekker Monument tea set. 2012. Porcelain, h. $29 \mathrm{~cm}$ (Zulu warrior teapot), $26 \mathrm{~cm}$ (Voortrekker maiden teapot) (photo courtesy of the artist; http://cargocollective.com/Leanie/ The-Most-Amazing-Tea-Set-Ever)

Figure 347: Commemorative medal issued by mayor of Johannesburg for inauguration of Voortrekker Monument. 1949 (courtesy of VTM Museum VTM 549; photo the authors)

Figure 348: Commemorative medal issued for the quarter-centenary of Voortrekker Monument. 1974 (courtesy of VTM Museum VTM 889; photo the authors)

Figure 349: Frikkie Kruger. Model of Voortrekker Monument. 1949. Metal, h. 16 cm (courtesy of VTM Museum VTM 1646; photo the authors)

Figure 350a: Aerial view of commemorative laager at Blood River. 1971 (photo courtesy of Freddy Reck, www. Reckfilm.de

Figure 350b: One of sixty-four full-size Voortrekker wagons replicated for commemorative laager at Blood River. 1971. Bronzed cast iron (photo the authors)

Figure 351: Harry Atkins. Frieze of the Jansen extension of Voortrekker Museum, Pietermaritzburg. 1959. Stone (photo courtesy of Louis Eksteen)

Figure 352: Ivan Mitford-Barberton. Bible Monument, Grahamstown. 1962. Bronze panels with English settlers presenting Bible (left side of monument) to Voortrekkers (right side) (photos the authors)

Figure 353: Isa Steynberg. Three panels of the Vegkop Monument: Attack, Flight of Ndebele, Help from Rolong. 1984. Bronze, each $0.9 \times 1.39 \mathrm{~m}$ (photo courtesy of Vegkop Monument)

Figure 354: W.H. Coetzer. Envelope for centenary ossewatrek with Voortrekker Memorial Fund stamps (1933-36), addressed to SVK chair. 1938 (courtesy of ARCA PV94 1/75/19 photo the authors)

Figure 355: Pegasus and Mobiloil poster for the ossewatrek. 1938 (photo courtesy HF Archives GTR 16)

Figure 356: J.H. Pierneef. Painting of the Trek used on cover of commemorative publication for Die Huisgenoot, 1938 (courtesy of UCT Libraries)

Figure 357: J.H. Pierneef. Linocut for the cover of centenary publication, Die Volkstem, 1938 (courtesy of UP Archives, Moerdyk files)

Figure 358: W.H. Coetzer. Die beloofde land (The promised land). Cover of commemorative pull-out section of Die Brandwag, 1938 (courtesy of ARCA PV188/20; photo the authors)

Figure 359: W.H. Coetzer. Monument Onthulling (inauguration). 1949. Oil on board, $66.7 \times 40.8 \mathrm{~cm}$. Used for cover of commemorative publication in Die Transvaler (courtesy of DNMCH HG 54517; photo Jan Middeljans)

Figure 360: J.H. Pierneef. Die Voortrekkermonument. 1949. Oil on canvas, $144 \times 154 \mathrm{~cm}$ (courtesy of VTM Museum OV 106; photo ID 46182592 @ Kaido Rummel, dreamstime.com)

Figure 361: Die Kerkblad Eeufeesuitgawe (centenary publication), 7 December 1938. Cover with Moerdyk's Drawing 4, entitled 'Servants of the Most High' (courtesy of UP Archives, Moerdyk collection)

Figure 362: Diane Victor. Monument. 2007. Charcoal, $100 \times 150 \mathrm{~cm}$ (photo courtesy of the artist and David Krut Publishing)

Figure 363: W.H. Coetzer. Voortrekkermonument. Pencil (courtesy of Museum Africa; photo the authors)

Figure 364: Images of the Voortrekker Monument in various media in the Monument’s collection (photo @ Die Erfenisstigting; Voortrekker Monument 1938-2018, 66)

Figure 365: Anton Kannemeyer. $n$ is for nightmare (monument). 2008. 8-colour lithograph, $67 \times 57 \mathrm{~cm}$ (photo courtesy of the artist)

Figure 366: Conrad Botes. 'Backpage’ of Bitterkomix 11, June 2001 (photo courtesy of Anton Kannemeyer and Conrad Botes)

Figure 367: Conrad Botes. Cover of Best of Bitterkomix 1 with the story of Blood River. 1999 (courtesy of the artist) 
Figure 368: Conrad Botes. Two frames from Best of Bitterkomix 1. 1999 (courtesy of the artist)

Figure 369: 'Dina - blom van die maand' (flower of the month). Cover of Loslyf June 1995, 125

Figure 370: Photographs of TV star Michelle Pienaar on the cenotaph, Voortrekker Monument (Taalgenoot April 2006; photos courtesy of VTM)

Figure 371: David Goldblatt. Child with a replica of a Zulu hut at the Voortrekker Monument, on the Day of the Covenant, Pretoria. December, 1963. 1963. Silver gelatin print on fibre-based paper. Edition of 10 (photo courtesy the David Goldblatt Legacy Trust and Goodman Gallery)

Figure 372: Gisèle Wulfsohn. Clothing designers Shanie Boerstra and Jerome Argue, Voortrekker Monument, Pretoria, 1985 (photo courtesy of Mark Trapido and Paul Weinberg)

Figure 373: Minnette Vári . Chimera. 2001. Installation shot (photo courtesy of the artist)

Figure 374: Minnette Vári . Chimera. 2001. Installation shot (photo courtesy of the artist)

Figure 375: Minnette Vári . Chimera. 2001. Video still (photo courtesy of the artist)

Figure 376: Minnette Vári . Chimera. 2001. Video still (photo courtesy of the artist)

Figure 377: Pieter Hugo. At the Voortrekker Monument, 2013. C-print, edition of five $104.7 \times 139.5 \mathrm{~cm}$; edition of nine $82.5 \times 109.8 \mathrm{~cm}$ (photo courtesy of the artist)

Figure 378: Abrie Fourie. Detail, Voortrekker Monument, South Africa, 2001. Lambda print diasec, $80 \times 120 \mathrm{~cm}$ (photo courtesy of the artist)

Figure 379: Abrie Fourie.Waymark/Wanton, 1900-2000. Lightjet print, $34 \times 42 \mathrm{~cm}$ (photo courtesy of the artist)

Figure 380: Dewald van Helsdingen. Photograph of Pink Voortrekker Monument, Cool Capital festival, Pretoria 2014 (photo courtesy of Carla Crafford)

Figure 381: Daniel Rankadi Mosako. Settlements. 1996. Acrylic and oil on board. $80 \times 70 \mathrm{~cm}$. (photo courtesy of artist)

Figure 382: The Voortrekker Monument (photo courtesy of HF Archives F 39.1.30 k)

Plan with layout of scenes of the frieze in Hall of Heroes at the end (plan drawing Tobias Bitterer)

Three-page foldout at the end: Frieze of the Voortrekker Monument (courtesy of VTM; photos Russell Scott) 